\title{
ANALISIS RASIO KEUANGAN DAERAH UNTUK MENILAI KINERJA KEUANGAN DAERAH KABUPATEN BULUKUMBA
}

\author{
Baso R ${ }^{(1)}$, Nurul Wahyuni ${ }^{(2)}$,Sumarni $\mathbf{S}^{(3)}$ \\ ${ }^{(1)}$ (Sekolah Tinggi Ilmu Ekonomi Wira Bhakti Makassar) \\ ${ }^{(2)}$ (Mahasiswa Magister Akuntansi Universitas Hasanuddin) \\ ${ }^{(3)}$ (Sekolah Tinggi Ilmu Ekonomi Wira Bhakti Makassar) \\ basoranungkalobe@gmail.com
}

\begin{abstract}
Tujuan dari penelitian ini adalah untuk mengetahui kinerja pemerintah daerah Kabupaten Bulukumba dalam hal rasio keuangan dalam Anggaran Pendapatan dan Belanja Daerah (APBD). Metode analisis yang digunakan adalah metode deskriptif (metode deskriptif kuantitatif), yaitu dengan menetapkan konsep penghitungan Rasio Keuangan dalam mengukur kinerja keuangan, dengan menghitung Rasio Keuangan dari realisasi anggaran yang terkandung dalam APBD dan Laporan Realisasi APBD untuk 2014 Periode -2017. Hasil penelitian menunjukkan bahwa independensi Pemerintah Kabupaten Bulukumba dalam memenuhi persyaratan pendanaan untuk melaksanakan tugas-tugas pemerintah, pengembangan, dan pelayanan sosial kepada masyarakat masih sangat rendah karena berada pada $0 \%-25 \%$, meskipun PAD telah meningkat dari tahun ke tahun, yaitu dari 8,73\% pada tahun 2015 menjadi 10,04\% pada tahun 2016 dan $16,54 \%$ pada tahun 2017 berarti bahwa peningkatan tersebut tidak signifikan terhadap peningkatan kemandirian finansial. Efektivitas dan efisiensi yang ditunjukkan pada tahun 2015 memiliki rasio efektivitas 93,83\% dan rasio efisiensi 8,48\%, pada 2016 memiliki rasio efektivitas $89,52 \%$ dan rasio efisiensi 8,24\%, dan pada 2017 memiliki rasio efektivitas efisiensi 82,98\% rasio 13,95\%. Ini berarti bahwa kinerja Pemerintah Daerah Kabupaten Bulukumba dalam mewujudkan pendapatan asli daerahnya cukup efektif dan sangat efisien.
\end{abstract}

Keywords: Independence Ratio, Effectiveness Ratio, Efficiency Ratio

\section{Latar Belakang}

\section{PENDAHULUAN}

Pengelolaan keuangan daerah yang diamanatkan oleh undangundang pemerintahan daerah adalah efesien, efektif, ekonomis, transparan, dan bertangung jawab dengan memperhatikan rasa keadilan, kepatutan,dan kemanfaatan bagi masyarakat. Pengelolaan keuangan daerah merupakan 
salah satu instrument penting dalam mewujudkan tujuan negara untuk memajukan kesejahteraan rakyat. Kemampuan pemerintah daerah dalam mengelola keuangannya dituangkan dalam Anggaran Pendapatan dan Belanja Daerah (APDB) yang mana menggambarkan kemampuan pemerintah daerah dalam membiayai semua kegiatan pembangunan.

Kinerja keuangan dapat menunjukan bagaimana kondisi keuangan pemerintah serta kemampuan pemerintah dalam memperoleh dan menggunakan dana untuk pembangunan negara. Pengukuran kinerja keuangan sangat penting untuk menilai akuntabilitas organisasi dan manajer dalam menghasilkan pelayanan publik yang lebih baik. Salah satu alat untuk menganalisis kinerja keuangan pemeritah dalam mengelolah keuangan daerah yaitu dengan melakukan analisis rasio keuangan. Menurut Mahmudi (2010:142) analisis rasio keuangan terdiri dari rasio derajat desentalisasi, rasio ketergantungan keuangan daerah, rasio kemandirian, rasio efektivitas PAD, rasio efektivitas pajak daerah dan rasio derajat kontribusi BUMD. Penelitian ini bertujuan untuk mengetahui kinerja pada pemerintah daerah Kabupaten Bulukumba ditinjau dari rasio keuangan pada Anggaran Pendapatan dan Belanja Daerah (APBD).

\section{TELAAH LITERATUR DAN PENGEMBANGAN HIPOTESIS}

\section{Pengukuran Kinerja}

Analisis keuangan adalah usaha mengidentifikasi ciri-ciri keuangan berdasarkan laporan yang tersedia. Analisis rasio keuangan pada APBD dilakukan dengan membandingkan hasil yang dicapai dari satu periode dibandingkan dengan periode sebelumnya sehingga dapat diketahui bagaimana kecenderungan yang terjadi.

\section{Rasio Kemandirian Keuangan Daerah}

Kemandirian keuangan daerah (otonomi fiskal) mengindikasikan kemampuan Pemerintah Daerah dalam membiayai sendiri kegiatan pemerintahan, pembangunan, dan pelayanan masyarakat yang telah membayar pajak dan retribusi sebagai sumber pendapatan daerah (Abdul 
Halim,2012). Selanjutnya Abdul Halim (2012) menyatakan bahwa kemandirian keuangan daerah ditunjukkan oleh besar kecilnya pendapatan asli daerah (PAD) dibandingkan dengan pendapatan daerah yang berasal dari sumber lainnya misalnya bantuan pemerintah pusat (transfer pusat) maupun dari pinjaman Kemandirian daerah ditunjukkan oleh besar kecilnya Rasio kemandirian juga mengerah digambarkan ketergantungan daerah terhadap sumber dana eksternal, terutama dari pemerintah pusat dan provinsi.

Semakin tinggi rasio kemandirian daerah, tingkat ketergantungan terhadap bantuan pihak eksternal (terutama pemerintah pusat dan provinsi) semakin rendah, dan sebaliknya. Rasio kemandirian juga menggambarkan tingkat partisipasi masyarakat dalam pembangunan daerah. Semakin tinggi rasio kemandirian, semakin tinggi partisipasi masyarakat dalam membayar pajak dan retribusi daerah yang merupakan komponen utama pendapatan asli daerah. Semakin tinggi masyarakat membayar pajak dan retribusi daerah menggambarkan bahwa timgkat kesejahteraan masyarakat semakin tinggi.

Tabel 1. Tingkat Kemandirian dan Kemampuan Keuangan Daerah

\begin{tabular}{|c|c|}
\hline Kemampuan Keuangan & Kemandirian (\%) \\
\hline Rendah Sekali & $0 \%-25 \%$ \\
Rendah & $25 \%-50 \%$ \\
Sedang & $50 \%-75 \%$ \\
Tinggi & $75 \%-100 \%$ \\
\hline
\end{tabular}

Sumber : Kepmendagri No.690.900.327 tahun 1996

\section{Rasio Efektifitas}

Rasio ini menggambarkan kemampuan pemerintah daerah dalam merealisasikan pendapatan asli daerah yang direncanakan dibandingkan dengan target yang ditetapkan berdasarkan potensi riil daerah. Pemda dikatakan mampu menjalankan tugasnya bila rasio yang dicapai minimal sebesar 1 atau 100 persen. tetapi semakin tinggi rasio efektivitas berarti kemampuan daerah semakin baik. Guna memperoleh ukuran yang lebih 
baik, rasio ini perlu didampingi dengan rasio efisiensi. Pemerintah telah menyusun pedoman penilaian tingkat efektivitas keuangan daerah, melalui Kepmendagri No.690.900.327 tahun 1996 berikut ini :

Tabel 2. Kriteria Efektivitas Keuangan Daerah

\begin{tabular}{|c|c|}
\hline Kriteria Efektivitas & Persentase Efektifitas (\%) \\
\hline Sangat Efektif & $>100$ \\
\hline Efektif & $>90-100$ \\
\hline Cukup Efektif & $>80-90$ \\
\hline Kurang Efektif & $>60-80$ \\
\hline Tidak Efektif & $\leq 60$ \\
\hline
\end{tabular}

Sumber: Kepmendagri No.690.900.327 tahun 1996

\section{Rasio Efisiensi}

Rasio efisiensi menggambarkan perbandingan antara besarnya biaya yang dikeluarkan untuk memperoleh pendapatan dengan realisasi pendapatan yang diterima. Pemda dikatakan efisien jika rasio yang dicapai kurang dari 1 (satu) atau di bawah 100 persen. Semakin kecil rasio efisiensi berarti kinerja pemerintah daerah semakin baik. Pemda perlu menghitung secara detail besarnya biaya yang dikeluarkan untuk merealisasikan seluruh pendapatan yang diterimanya, sehingga dapat diketahui cara memungut pendapatannya efisien atau tidak. Hal ini perlu dilakukan, meskipun Pemda berhasil merealisasikan penerimaan pendapatannya sesuai target yang ditetapkan, namun ternyata biaya untuk memperoleh pendapatan lebih besar dari capaian pendapatannya, maka itu menjadi sia-sia. Suatu kegiatan dikatakan telah dikerjakan secara efisien jika pelaksanaan pekerjaan tersebut telah mencapai hasil (output) dengan biaya (input) yang terendah atau dengan biaya minimal diperoleh hasil yang diinginkan (Mahsun, 2006: 187).

Rasio efisiensi diukur dengan membandingkan realiasi belanja daerah dengan anggaran belanja daerah (Suyana, 2008: 33) :

\begin{tabular}{|c|c|c|}
\hline \multirow{3}{*}{ Rasion Efisiensi = } & Realisasi Belanja Daerah & \multirow{3}{*}{ x $100 \%$} \\
\hline & & \\
\hline & Anggaran Belanja Daerah & \\
\hline
\end{tabular}


Tabel 3. Kriteria Efisiensi Kinerja Keuangan

\begin{tabular}{|c|c|}
\hline Kriteria Efisiensi & Persentase Efisiensi \\
\hline $100 \%$ keatas & Tidak Efisien \\
\hline $90 \%-100 \%$ & Kurang Efisien \\
\hline $80 \%-90 \%$ & Cukup Efisien \\
\hline $60 \%-80 \%$ & Efisien \\
\hline Kurang dari $60 \%$ & Sangat Efisien \\
\hline
\end{tabular}

Sumber : Kepmendagri No.690.900.327 tahun 1996

\section{Rasio Keserasian}

Rasio keserasian merupakan rasio yang mendeskripsikan aktivitas Pemerintah Daerah dalam memprioritaskan alokasi dananya pada belanja rutin dan belanja pembangunan secara optimal. Semakin tinggi prosentase dana yang dialokasikan untuk belanja rutin berarti prosentase belanja investasi yang dipakai untuk menyediakan sarana prasarana ekonomi masyarakat semakin kecil (Abdul Halim, 2012). Selanjutnya rasio keserasian dapat di formulasikan sebagai berikut :

Rasio Belanja Operasi Terhadap APBD $=\frac{\text { Total Belanja Rutin }}{\text { Total APBD }} \times 100 \%$

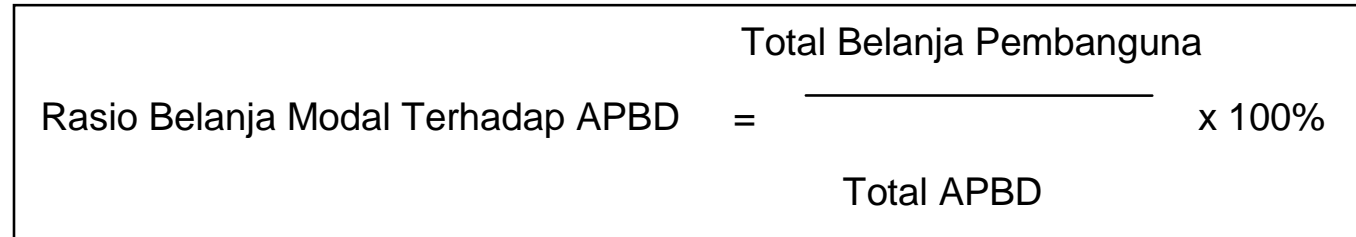

HIngga saat Inı belum ada pedoman yang Ideal tentang besarnya rasio belanja rutin maupun rasio belanja modal, karena sangat dipengaruhi dinamika pembangunan dan kebutuhan investasi yang diperlukan untuk mencapai pertumbuhan yang ditargetkan. (Abdul Halim, 2012).

\section{Rasio Pertumbuhan}

Rasio pertumbuhan mengukur kemampuan Pemerintah Daerah dalam mempertahankan dan meningkatkan keberhasilan yang telah dicapai selama beberapa periode (Abdul Halim, 2012). Jika pertumbuhan untuk masingmasing komponen sumber pendapatan dan pengeluaran sudah diketahui, 
maka dapat digunakan untuk menilai potensi mana yang perlu mendapat perhatian.

Rasio Pertumbuhan PAD $=\frac{\text { Realisasi Penerimaan PAD } x_{n}-x_{n-1}}{\text { Realisasi Penerimaan PAD } x_{n-1}} \times 100 \%$

\section{Realisasi Pertumbuhan $\Sigma$ Pendapatan $x_{n}-x_{n-1}$}

Rasio Pertumbuhan $\Sigma$ Pendapatan $=$ $x 100 \%$

Realisasi Pertumbuhan $\Sigma$ Pendapatan $\mathrm{x}_{\mathrm{n}-1}$

\section{Kerangka Pemikiran}

Untuk arah dan konsep penelitian pada pemerintah daerah Bulukumba, maka peneliti membuat kerangka pemikiran sebagai berikut :

Gambar 1 . Kerangka Pemikiran

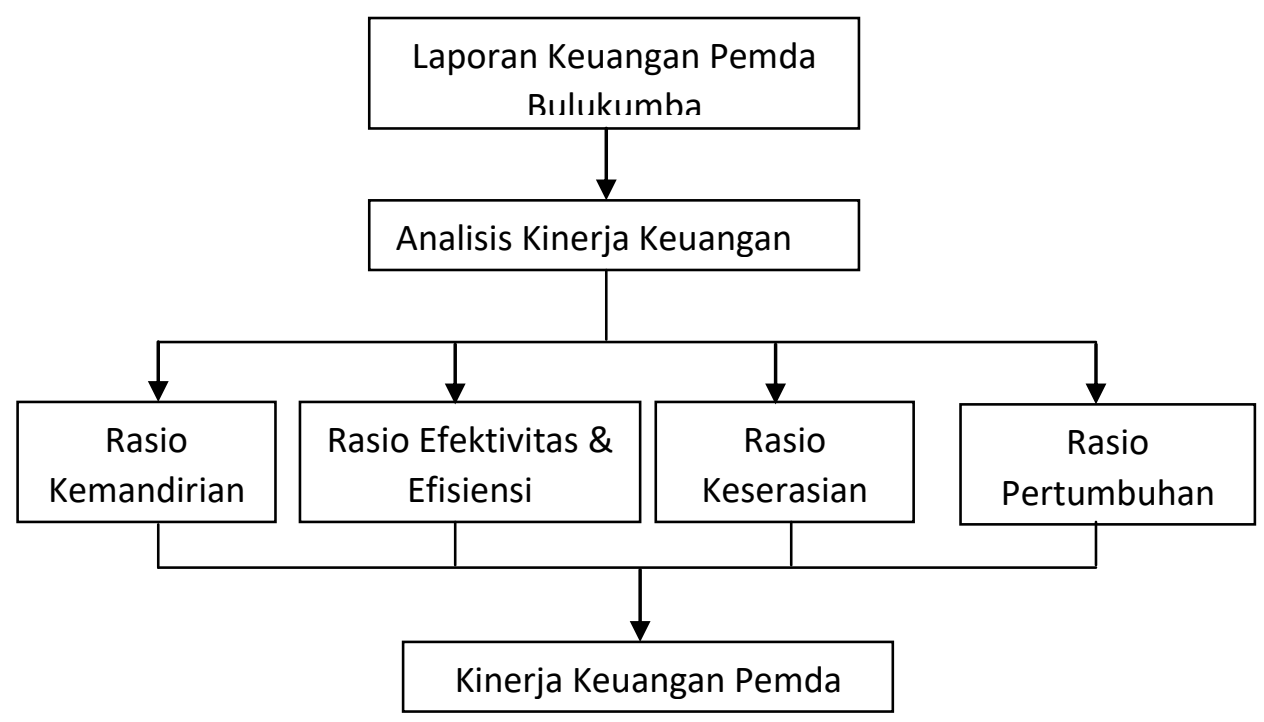

\section{HASIL DAN PEMBAHASAN}

\section{Hasil Penelitian}

\section{Rasio Kemandirian Keuangan}

Untuk menilai tinggi rendahnya rasio kemandirian pemerintah daerah, bisa mengacu pada Kepmendagri No.690.900.327 tahun 1996. Rasio Kemandirian Pemerintah Kabupaten Bulukumba dapat dihitung sebagai berikut: 


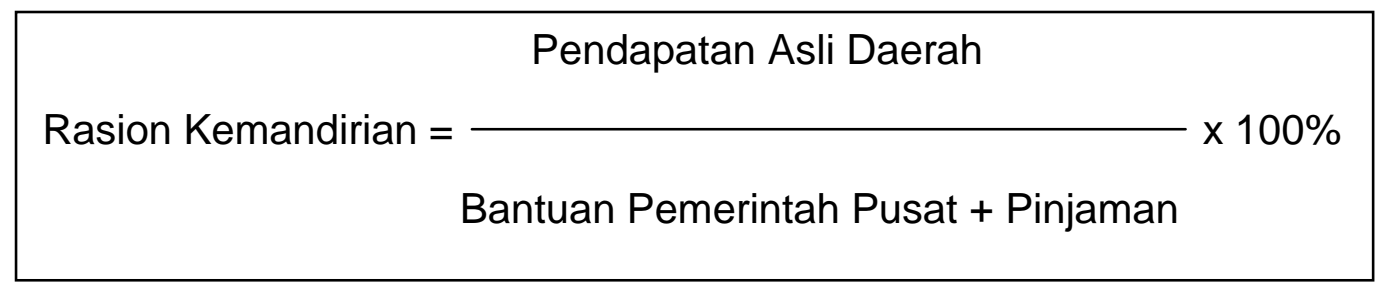

Tabel 4.Perhitungan Rasio Kemandirian Pemerintah Daerah Kabupaten Bulukumba Tahun Anggaran 2015-2017:

\begin{tabular}{|l|c|c|c|c|}
\hline Tahun & $\begin{array}{c}\text { Pendapatan Asli Daerah } \\
(\mathrm{Rp})\end{array}$ & $\begin{array}{c}\text { Pendapatan Transfer } \\
(\mathrm{Rp})\end{array}$ & $\begin{array}{c}\text { Pinjaman } \\
(\mathrm{Rp})\end{array}$ & $\begin{array}{c}\text { Rasio } \\
(\%)\end{array}$ \\
\hline 2015 & 106.037 .895 .838 & 1.169 .575 .690 .784 & 44.081 .663 .537 & $8,74 \%$ \\
\hline 2016 & 128.236 .254 .047 & 1.238 .658 .649 .153 & 38.249 .979 .495 & $10,04 \%$ \\
\hline 2017 & 201.080 .429 .101 & 1.215 .071 .169 .417 & 0 & $16,55 \%$ \\
\hline
\end{tabular}

Sumber : Data diolah

Berdasarkan tabel 4 di atas, nampak bahwa Pemerintah Kabupaten Bulukumba tingkat kemandiriannya mengalami peningkatan hal ini bisa di lihat dari adanya peningkatan rasio kemandirian dari 10,04\% menjadi 16,55 \%. Tetapi jika hasil rasio kemandirian dibandingkan dengan pedoman tingkat kemandirian dan kemampuan keuangan dari Kepmendagri tahun 1996, maka Pemerintah Kabupaten Bulukumba untuk tahun 2015 dan 2017 tingkat kemampuan keuangannya masih rendah sekali.

\section{Rasio Efektivitas Keuangan}

\begin{tabular}{|c|} 
Rasion Efektivitas $=$ \\
Target Penerimaan PAD Yang Ditetapkan Berdasarkan \\
$\begin{array}{c}\text { Potensi Rill Daerah } \\
\text { Terimaan PAD }\end{array}$
\end{tabular}

Tabel 5. Perhitungan Rasio Efektifitas

\begin{tabular}{|l|c|c|l|}
\hline \multirow{2}{*}{ Tahun } & Target PAD & Realisasi PAD & \multicolumn{1}{c|}{$\begin{array}{c}\text { Rasio Efektivitas } \\
(\%)\end{array}$} \\
\hline 2015 & $(\mathrm{Rp})$ & $(\mathrm{Rp})$ & $93,84 \%$ \\
\hline 2016 & 112.996 .638 .470 & 106.037 .895 .838 & $89,52 \%$ \\
\hline 2017 & 143.247 .500 .513 & 128.236 .254 .047 & $82,99 \%$ \\
\hline
\end{tabular}

Sumber : Data diolah

Berdasarkan tabel di atas nampak bahwa terjadi penurunan rasio efektifitas dari tahun $201593,84 \%$ menjadi 89,52\% pada tahun 2016, dan pada tahun 2017 menjadi 82,99\% sehingga kriteria efektifitas menurun dari 
"efektif" menjadi "cukup efektif". Dengan demikian dapat disimpulkan bahwa Pemerintah Kabupaten Bulukumba pada tahun 2017 telah cukup efektif dalam mengelola PAD nya.

\section{Rasio Efisiensi Keuangan}

\section{Biaya Belanja Daerah}

Rasion Efisiensi $=$ $x 100 \%$

Anggaran Belanja Daerah

Tabel 6. Perhitungan Rasio Efisiensi

\begin{tabular}{|c|c|c|c|}
\hline Tahun & $\begin{array}{l}\text { Biaya Belanja Daerah } \\
\text { (Rp) }\end{array}$ & $\begin{array}{l}\text { Anggaran Belanja Daerah } \\
\text { (Rp) }\end{array}$ & $\begin{array}{c}\text { Rasio Efektivitas } \\
(\%)\end{array}$ \\
\hline 2015 & $1.310 .827 .049 .799,79$ & $1.249 .121 .038 .587,89$ & $105 \%$ \\
\hline 2016 & 1.308.476.678.769,96 & $1.554 .817 .772 .702,87$ & $84 \%$ \\
\hline 2017 & $1.322 .588 .737 .134,00$ & $1.440 .874 .962 .495,71$ & $92 \%$ \\
\hline
\end{tabular}

Sumber : Data diolah

Tabel di atas diketahui bahwa rasio efisiensi dari 105\% di tahun 2015 menjadi 84\% di tahun 2016 dan meningkat sebesar 92\% di tahun 2017. Hal ini menunjukkan bahwa Pemerintah Kabupaten Bulukumba dalam mengelola pendapatan asli daerahnya sudah "kurang efisien" karena hasil rasio efisiensi di atas dari dari $90 \%$.

\section{Rasio Keserasian Keuangan}

Rasio Belanja Operasi Terhadap APBD $=\frac{\text { Total Belanja Rutin }}{\text { Total APBD }} \times 100 \%$

Tabel 7.Perhitungan Rasio Keserasian (Belanja Rutin dibanding Total APBD)

\begin{tabular}{|l|c|c|c|}
\hline Tahun & Belanja Operasi & Total APBD & $\begin{array}{c}\text { Rasio Belanja } \\
\text { Operasi } \\
\text { dibandingkan Total } \\
\text { APBD }(\%)\end{array}$ \\
\hline 2015 & 985.389 .171 .775 & 1.310 .827 .049 .799 & $75,17 \%$ \\
\hline 2016 & 1.016 .063 .724 .141 & 1.308 .476 .678 .769 & $77,65 \%$ \\
\hline 2017 & 978.149 .931 .746 & 1.322 .588 .737 .134 & $73,96 \%$ \\
\hline
\end{tabular}

Sumber: Data diolah 


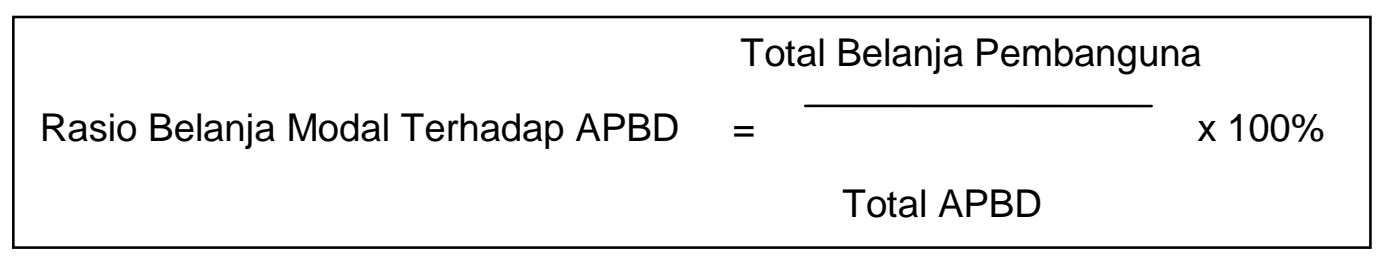

Tabel 8.Perhitungan Rasio Keserasian (Belanja Modal dibanding Total APBD)

\begin{tabular}{|l|c|c|c|}
\hline Tahun & Belanja Modal & Total APBD & $\begin{array}{c}\text { Rasio Belanja } \\
\text { Modal dibandingkan } \\
\text { Total APBD (\%) }\end{array}$ \\
\hline 2015 & 325.437 .878 .024 & 1.310 .827 .049 .799 & $24,83 \%$ \\
\hline 2016 & 291.771 .235 .808 & 1.308 .476 .678 .769 & $22,30 \%$ \\
\hline 2017 & 344.329 .477 .188 & 1.322 .588 .737 .134 & $26,03 \%$ \\
\hline
\end{tabular}

Sumber: Data diolah

Dari perhitungan rasio keserasian di atas nampak bahwa sebagian besar dana yang dimiliki Pemerintah Kabupaten Bulukumba masih digunakan untuk kebutuhan belanja operasi walaupun terjadi peningkatan dari $75,17 \%$ (2015) menjadi $77,65 \%$ (2016) dan mengalami penurunan 73,96\% (2017) . Demikian pula rasio belanja modal terhadap APBD masih relatif kecil, walaupun sudah terdapat kenaikan dari 24,83\% (2015) menjadi $22,30 \%$ (2016) dan mengalami peningkatan 26,03\% (2017).

\section{Rasio Pertumbuhan Keuangan}

Tabel 9. Perhitungan Rasio Pertumbuhan Pendapatan

\begin{tabular}{|l|c|c|l|l|}
\hline Tahun & $\begin{array}{c}\text { Pendapatan Asli Daerah } \\
(\mathrm{Rp})\end{array}$ & $\begin{array}{c}\text { Total Pendapatan } \\
(\mathrm{Rp})\end{array}$ & $\begin{array}{c}\text { Rasio } \\
\text { Pertumbuhan }\end{array}$ & $\begin{array}{c}\text { Rasio } \\
\text { Pertumbuhan } \\
\text { Pendapatan } \\
(\%)\end{array}$ \\
\hline 2015 & 106.037 .895 .838 & 1.332 .345 .752 .332 & - & - \\
\hline 2016 & 128.236 .254 .047 & 1.372 .714 .249 .806 & $20,93 \%$ & $3,02 \%$ \\
\hline 2017 & 201.080 .429 .101 & 1.431 .800 .027 .268 & $56,80 \%$ & $4,30 \%$ \\
\hline
\end{tabular}

Sumber : Data diolah

Tabel 10. Perhitungan Rasio Pertumbuhan Belanja

\begin{tabular}{|l|c|c|l|l|}
\hline Tahun & $\begin{array}{c}\text { Belanja Operasi } \\
(\mathrm{Rp})\end{array}$ & $\begin{array}{c}\text { Belanja Modal } \\
(\mathrm{Rp})\end{array}$ & $\begin{array}{c}\text { Rasio } \\
\text { Pertumbuhan }\end{array}$ & $\begin{array}{c}\text { Rasio } \\
\text { Pertumbuhan } \\
\text { Belanja Modal } \\
(\%)\end{array}$ \\
\hline 2015 & 985.389 .171 .775 & 325.437 .878 .024 & - & - \\
\hline 2016 & 1.016 .063 .724 .141 & 291.771 .235 .808 & $3,11 \%$ & $-10,34 \%$ \\
\hline 2017 & 978.149 .931 .746 & 344.329 .475 .188 & $-3,79 \%$ & $5,25 \%$ \\
\hline
\end{tabular}

Sumber : Data diolah 
Berdasarkan tabel 9 di atas dapat diketahui bahwa pada tahun 2016 PAD Pemda Kabupaten Bulukumba mengalami pertumbuhan yakni sebesar $20,93 \%$. Demikian juga untuk total pendapatan di tahun 2016 mengalami pertumbuhan sebesar 3,02\% di tahun 2017 mengalami pertumbuhan sebesar 56,80\%. Demikian pula untuk total pendapatan di tahun 2017 sebesar 4,30\%. Sedangkan untuk belanja operasi (tabel 10) mengalami pertumbuhan sebesar $3,11 \%$ serta total pertumbuan belanja sebesar 10,34\% di tahun 2016 dan untuk belanja modal -3,79\% dan total belanja modal yakni sebesar 5,25\% di tahun 2017 .

\section{Pembahasan}

\section{Kinerja Keuangan Pemda Kabupaten Bulukumba di lihat dari sisi Kemandirian Keuangan}

Berdasarkan perhitungan Rasio Keuangan Daerah Kabupaten BulukumbaTahun Anggaran 2015-2017 diketahui bahwa rasio kemandirian keuangan daerah Kabupaten Bulukumba pada tahun anggaran 2015 sebesar 8,73\%, naik pada tahun 2016 sebesar 10,04\% dan pada tahun 2017 mengalami penurunan sebesar $16,55 \%$ atau berada pada skala rasio interval 0 - 25 (rendah sekali). Hal ini menunjukkan bahwa kemandirian daerah dalam mencukupi kebutuhan pembiayaan untuk melakukan tugas-tugas pemerintahan, pembangunan dan pelayanan masyarakat masih sangat rendah. Meskipun Pendapatan Asli Daerah yang mengalami peningkatan dari tahun ke tahun tetapi nilai pendapatan Asli Daerah masih sangat rendah. Rasio tersebut menunjukkan pemerintah kabupaten Bulukumba belum mampu membiayai kegiatannya (belum mandiri). Oleh karena itu, perlu adanya usaha untuk mengurangi ketergantungan terhadap bantuan pihak ekstern (terutama pemerintahan pusat dan provinsi), baik melalui pengoptimalan sumber pendapatan asli daerah khusunya pada pendapatan lain-lain PAD yang sah yang mengalami penigkatan di tahun anggaran 20152017.

\section{Kinerja Keuangan Pemda Kabupaten Bulukumba di lihat dari sisi Rasio Efektifitas dan Efisiensi}

Berdasarkan hasil perhitungan rasio efektivitas dan efisiensi dapat 
dilihat bahwa rasio efektifitas Pemerintah Kabupaten Bulukumba dalam melakukan pemungutan pajak dan retribusi daerah yang merupakan sumber pendapatan asli daerah pada tahun 2015 adalah 93,84\%, 2016 yaitu $89,52 \% \%$ dan 2017 yaitu 82,98\%. Angka ini menunjukkan bahwa pemerintah daerah untuk tahun 2015 efektif dan tahun2016 serta 2017 cukup efektif dalam merealisasikan sumber pendapatan asli daerah khususnya dalam melakukan pemungutan retribusi daerah, hasil pengelolaan kekayaan daerah dan lain-lain Pendapatan Asli Daerah yang sah.

Sedangkan dari perhitungan rasio efisiensi diatas kinerja Pemerintahan Daerah Kabupaten Bulukumba dapat dikatakan sangat efisien karena dari perhitungan rasio dari tahun 2015 yaitu 8,48\%, 2016 yaitu 8,24\%, dan 2017 yaitu 13,95\% mengalami kenaikan pada tahun 2015 yang berarti adanya penurunan kinerja pada pemerintah, lalu pada tahun 2016 rasio efisiensinya mengalami penurunan yang menggambarkan meningkatnya kinerja pemerintah. Ini mengindifikasikan bahwa pemerintah daerah mengalami peningkatan kinerja dari segi efisiensinya melakukan pemungutan sumber pendapatan.

\section{Kinerja Keuangan Pemda Kabupaten Bulukumba di lihat dari sisi Rasio Aktivitas (Rasio Keseimbangan)}

Berdasarkan perhitungan rasio diatas terlihat sebagian besar dana yang dimiliki Pemerintah Daerah Kabupaten Bulukumba masih diprioritaskan untuk kebutuhan belanja operasi sehingga rasio belanja modal terhadap APBD masih relatif kecil. Belum ada patokan yang pasti berapa besarnya rasio belanja operasi maupun belanja modal terhadap APBD yang ideal karena sangat dipengaruhi oleh dinamisasi kegiatan pembangunan dan besarnya kebutuhan investasi yang diperlukan untuk mencapai pertumbuhan yang ditargetkan. Namun demikian, sebagai negara berkembang peranan pemerintah daerah untuk memacu pelaksanaan pembangunan masih relatif besar. Namun hal ini masih kurang diperhatikan oleh Pemerintah Daerah Kabupaten Bulukumba karena terlihat rasio belanja modal dari tahun ke tahun menurun. 


\section{Kinerja Keuangan Pemda Kabupaten Bulukumba di lihat dari sisi Rasio Pertumbuhan}

Dari perhitungan rasio Pertumbuhan dapat dijelakan bahwa pertumbuhan APBD Kabupaten Bulukumba pada Tahun Anggaran 20152016 pertumbuhan pendapatan asli daerah, pertumbuhan pendapatan, pertumbuhan belanja operasi menunjukkan pertumbuhan yang positif, hanya belanja modal yang menunjukkan pertumbuhan negatif. Sedangkan pada tahun 2015-2017 pertumbuhan pendapatan dan pertumbuhan belanja operasi mengalami pertumbuhan yang positif. Sebaliknya dengan pertumbuhan pendapatan asli daerah dan pertumbuhan belanja modal mengalami pertumbuhan yang negatif.

\section{PENUTUP}

\section{Kesimpulan}

Berdasarkan hasil penelitian yang telah dibahas pada bab sebelumnya, maka dapat disimpulkan bahwa :

a. Kemandirian Pemerintah Daerah Kabupaten Bulukumba dalam memenuhi kebutuhan dana untuk penyelenggaraan tugas-tugas pemerintahan, pembangunan, dan pelayanan sosial kepada masyarakat masih sangat rendah karena berada pada angka 0\%-25\%, meskipun PAD mengalami peningkatan dari tahun ke tahun, yaitu dari 8,73\% pada tahun 2015 menjadi 10,04\% pada tahun 2016 dan 16,54\% pada tahun 2017. Tetapi perbedaan peningkatan tersebut tidak bermakna pada perbedaan peningkatan kemandirian keuangan.

b. Kinerja Pemerintah Daerah Kabupaten Bulukumba dalam merealiasasikan pendapatan asli daerahnya tergolong cukup efektif dan sangat efisiensi, yakni pada tahun 2015 memiliki rasio efektifitas 93,83\% dan rasio efisiensi 8,48\%, kemudian pada tahun 2016 memiliki rasio efektifitas sebesar $89,52 \%$ dan rasio efisiensi 8,24\%, dan pada tahun 2017 memiliki rasio efektifitas $82,98 \%$ rasio efisiensi sebesar $13,95 \%$.

c. Sebagian besar yang dimiliki Pemerintah Daerah Kabupaten Bulukumba masih diprioritaskan untuk mencukupi kebutuhan belanja operasi daripada 
belanja modal. Pelaksanaan pembangunan masih kurang diperhatikan oleh Pemerintah Daerah Kabupaten Bulukumba meskipun belanja modal dari tahun ke tahun mengalami penurunan dan peningkatan, terlihat pada tahun 2015 yaitu $10,10 \%$, dan 2017 yaiu $11,11 \%$, namun mengalami penurunan pada tahun 2016 yaitu $8,91 \%$.

d. Pertumbuhan APBD Pemerintah Daerah Kabupaten Bulukumba tahun anggaran 2015-2017 menunjukkan bahwa pertumbuhan pendapatan asli daerah dan pertumbuhan belanja modal menunjukkan pertumbuhan yang positif. Sedangkan pada pertumbuhan pendapatan dan pertumbuhan belanja operasi mengalami pertumbuhan yang negatif.

e. Kinerja keuangan pemerintah daerah Kabupaten Bulukumba selama periode penelitian (tahun 2015 sampai tahun 2017) baik karena hampir semua perhitungan rasio mengalami penigkatan kinerja. Hanya saja efektivitas dan efisiensi yang mengalami penurunan dari tahun ke tahun.

f. Hipotesis yang menyatakan kinerja keuangan Pemerintah Daerah Kabuaten Bulukumba di era otonomi daerah sudah baik di tinjau dari aspek rasio - rasio keuangan pemerintah tidak terbukti dalam rasio kemandirian karena rasio kemandirian berada pada interval $0-25$ (rendah sekali). Namun dari segi efektifitas dan efesiensi hipotesis tersebut terbukti yaitu pemerintah kabupaten bulukumba cukup efektif dalam mengelola PAD dan sangat efesien dalam mengelola penerimaan daerah dikaitkan dengan belanja daerah.

\section{Implikasi}

Hasil Penelitian ini dapat digunakan sebagai bahan koreksi untuk meningkatkan kinerja keuangannya pada tahun-tahun berikutnya.

\section{Keterbatasan dan Saran}

Berdasarkan hasil penelitian dari pembahasan tersebut, maka hal-hal yang dapat disarankan adalah sebagai berikut:

a. Pemerintah Daerah Kabupaten Bulukumba dapat menggunakan analisis rasio keuangan untuk melakukan penilaian dan evaluasi kinerja untuk kepentingan manajemen birokrasi pemerintah serta untuk menambah kualitas sistem informasi keuangan daerah. 
b. Lebih mengoptimalkan sumber-sumber pendapatan asli daerah yang ada maupun yang belum diolah agar dapat meningkatkan pendapatan asli daerah sehingga ketergantungan terhadap sumber daya ekstern dapat diminimalisir

c. Pemerintah Daerah Kabupaten Bulukumba sebaiknya memprioritaskan lagi pengalokasian dana yang dimiliki untuk belanja modal sehingga semakin bertambahnya sarana dan prasarana yang diharapkanakan mampu meningkatkan kesejahteraan masyarakatnya.

d. Pemerintah Daerah Kabupaten Bulukumba diharapkan dapat meningkatkan kemampuan semua pihak yang terlibat dalam penyusunan laporan keuangan, baik itu dengan memberikan bimbingan teknis dan pelatihan mengenai pengelolaan keuangan daerah. Dengan begitu diharapkan penyusunan laporan keuangan dapat berjalan dengan lancar dan tepat waktu sehingga memudahkan penyusunan Anggaran Pendapatan dan Belanja Daerah untuk tahun anggaran berikutnya serta dapat menjadi informasi yang relevan bagi pemakainnya

\section{DAFTAR PUSTAKA}

Anastasia, Melisa. 2012. Evaluasi Kinerja Keuangan Daerah Kabupaten Bulukumba. Skripsi. Universitas Hasanuddin. Makassar. http://repository.unhas.ac.id/handle/123456789/1616. Diakses Tanggal 25 Mei 2018.

Ananda, Candra Fajri. 2017. Pembangunan Ekonomi Daerah. Yogyakarta. Deepublish

Badan Pusat Statistik Kabupaten Bulukumba. 2018. Bulukumba dalam angka 2017. Badan Pusat Statistik Kabupaten Bulukumba. Bulukumba.

Badan Pusat Statistik Kabupaten Bulukumba. 2017. Produk Domestik Regional Bruto menurut Lapangan Usaha Kabupaten Bulukumba 2011-2016. Badan Pusat Statistik Kabupaten Bulukumba. Bulukumba.

Dayanto \& Asma Karim. 2015. Peraturan Daerah Responsip. Yogyakarta. Deepublish. 
Fuad, Mohammad Ramly. 2014. Pengantar akutansi keuangan daerah. Yogyakarta. deepublish

Fidelius. 2013. Analisis untuk Mengukur Kinerja Pengelolaan Keuangan Daerah Kota Menado. Jurnal EMBA. Vol.1 nomor 4.

Halim, Abdul. 2008. Akutansi Keuangan Daerah. Jakarta. Salemba Empat edisi 3

Kariangan, Hendra. 2017. Carut Marut Pengelolaan Keuamgam Daerah Di Era Otonomi Daerah. Depok. Kencana.

Mardiasmo. 2009.Akutansi Sektor Publik. Yogyakarta. Andi edisi 4

Mahsun, Mohamad. 2006, dalam Suyana, Utama M. 2007. Pengaruh Kinerja Keuangan Daerah Terhadap Kesejahteraan Masyarakat Pada Kabupaten/Kota di Provinsi Bali Tahun 2001 - 2006. Studi Kasus Pada 9 Kabupaten/Kota di Provinsi Bali.

Pramono, J. (2014). Analisis rasio keuangan untuk menilai kinerja keuangan pemerintah daerah (Studi Kasus pada pemerintah Kota Surakarta). Among Makarti, 7(13).

Rai, I Gusti Agung. 2008. Audit Kinerja Pada Sektor Publik. Jakarta. Salemba Empat

Sudaryo, Yoyo. Dkk. 2017. Keuangan Di Era Otonomi Daerah. Yogyakarta. Andi

Suyana Utama, 2008. Pengaruh kinerja keuangan daerah terhadap kesejahteraan masyarakat pada Kabupaten/Kota di Provinsi Bali. 